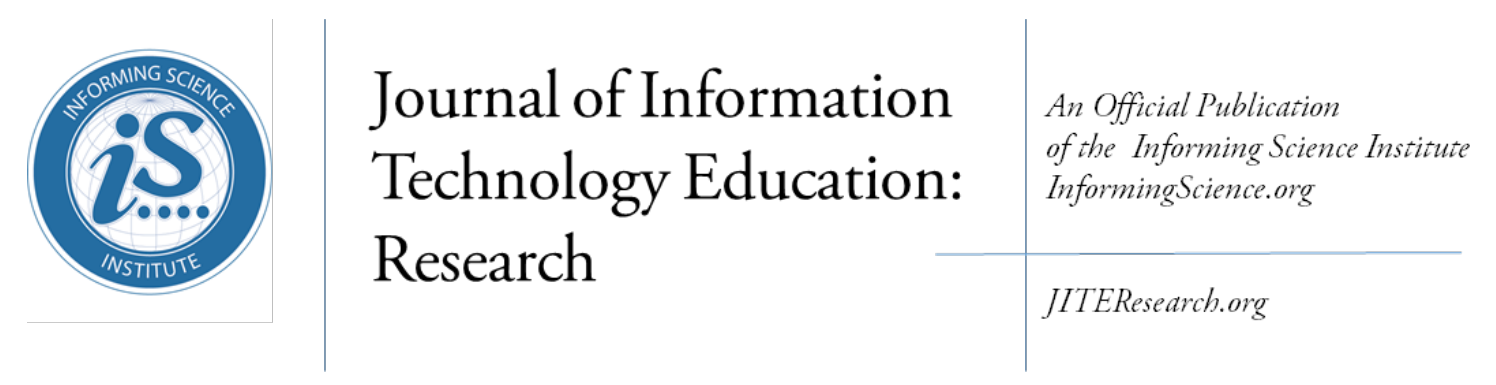

Volume 18, 2019

\title{
EFFECTIVE EVALUATION OF THE NON-TECHNICAL SKILLS IN THE COMPUTING DISCIPLINE
}

\author{
Maurice Danaher* \\ Kevin Schoepp \\ Ashley Ater Kranov \\ *Corresponding author
}

Zayed University, Abu Dhabi, UAE

maurice.danaher@zu.ac.ae

Independent Researcher, Tulum, Mexico

Washington State University, Pullman, WA, USA

kevinschoepp@gmail.com

kranova@live.com

\section{ABSTRACT}

Aim/Purpose

Assessing non-technical skills is very difficult and current approaches typically assess the skills separately. There is a need for better quality assessment of these skills at undergraduate and postgraduate levels.

Background

A method has been developed for the computing discipline that assesses all six non-technical skills prescribed by ABET (Accreditation Board for Engineering and Technology), the accreditation board for engineering and technology. It has been shown to be a valid and reliable method for undergraduate students

Methodology

The method is based upon performance-based assessment where a team of students discuss and analyze an ill-defined authentic issue over a 12-day period on a discussion board

Contribution

This is the first published method to assess all six skills simultaneously in computing and here it has been trialed with postgraduate students.

Findings

The results show that the method, though originally designed for undergraduates, can successfully be used with postgraduate students. Additionally, the postgraduate students found it to be very beneficial to their learning.

Recommendations for Practitioners

This method can successfully assess non-technical skills at tertiary level in the computing discipline and it can be adapted to other disciplines. Though designed for assessment it has been found to be an ideal method for teaching the skills at both undergraduate and post graduate levels.

Accepting Editor Man Fung (Kelvin) LO | Received: August 22, 2018 | Revised: November 2, 2018; January 5, 2019 | Accepted: January 16, 2019.

Cite as: Danaher, M., Schoepp, K., \& Ater Kranov, A (2019). Effective Evaluation of the Non-Technical Skills in the Computing Discipline. Journal of Information Technology Education: Research, 18, 1-18. https://doi.org/10.28945/4181

(CC BY-NC 4.0) This article is licensed to you under a Creative Commons Attribution-NonCommercial 4.0 International License. When you copy and redistribute this paper in full or in part, you need to provide proper attribution to it to ensure that others can later locate this work (and to ensure that others do not accuse you of plagiarism). You may (and we encourage you to) adapt, remix, transform, and build upon the material for any non-commercial purposes. This license does not permit you to use this material for commercial purposes. 
Effective Evaluation of the Non-Technical Skills in the Computing Discipline

Recommendations Compared with other assessment approaches this method has many advantages: for Researchers it is a direct method of measurement, it is a rigorous method and it assesses all skills simultaneously

Impact on Society Proficiency in non-technical skills is critical for development of knowledgebased economies. This method is a tool to assist in developing these skills.

Future Research Researchers can examine how the method benefits students in their context and examine if there are differences between their context and the UAE context presented here. Researchers can work on developing a rubric solely for postgraduate use i.e., to capture the range of levels among postgraduates.

Keywords computing education, learning outcomes, employability, transferable skills, assessment

\section{INTRODUCTION}

Non-technical skills (also known by terms such as professional, 21st century, transferable, soft skills) in the technology arena include, but are not limited to (a) the ability to function successfully on multicultural, multi-lingual and/or multi-disciplinary teams to analyze and resolve current problems, and

(b) the ability to evaluate impacts of proposed technical solutions in environmental, economic, socie$\mathrm{tal} /$ cultural and legal contexts. Worldwide, tertiary education and training programs strive to develop a solid foundation of non-technical skills in their students and employees to build human capacity and increase organizational effectiveness. The research described in this paper has been conducted in the United Arab Emirates (UAE). However, the research and results are relevant in all countries.

Educating students to become gainfully employed, productive and engaged members of society is the focus of UAE public education and economic policy. Recent swift cross-sector growth and diversification requires Emirati students and employees to attain the nation's ambitious sustainable human development goals. The country has emphasized the building of a capable workforce with a specific emphasis on building human capital in the STEM fields. Skills-based development goals and benchmarks are now being implemented at secondary and tertiary public education levels, as outlined in the UAE National Vision 2021 (UAE, 2010). The UAE strives to foster an environment where youth can grow knowledge, competencies, mindsets and values that will enable them with knowledge and skills for their own personal benefit and that of the society as a whole.

While substantial investment and improvement has been made in the UAE to increase the nontechnical skills of its young citizens and the nation's global competitiveness, particularly in the STEM fields, numerous reports highlight a stubborn gap between what employers want and what fresh graduates looking for work can demonstrate. Employers need fresh graduates and entry-level employees to demonstrate competency in non-technical skills and this misalignment between employer requirements and existing skills is a serious impediment to the development of the nation.

The challenge surrounding student and entry-level employee attainment of these skills is that employers prioritize them, graduates lack them, and they are considered difficult to teach and measure (Shuman, et al., 2005). Academic programs and industry alike struggle in generating accurate and actionable data to increase learning and application of core non-technical skills (Ater Kranov \& Khalaf, 2016). Most existing instruments are used to assess each skill individually without consideration of the implicit interaction necessary to achieve a skills set. Instruments that are not designed to complement one another and that rely heavily on perceptions are inadequate for data-driven curricular decision making. These constraints are problematic because they (a) do not provide direct measures of learning and (b) can make the assessment process resource intensive and cumbersome to implement.

The writers have developed a method known as the Computing Professional Skills Assessment (CPSA) that assesses the professional skills prescribed by ABET (Accreditation Board for Engineer- 
ing and Technology) for the computing discipline. (Henceforth we will use the ABET terminology of "professional skills" rather than "non-technical skills"). The method assesses all six ABET prescribed professional skills simultaneously and has been shown to be valid and reliable. It was designed for use with undergraduate students, but the top end of the CPSA Rubric was set to post graduate level performance. The CPSA has been used with over 400 undergraduate students and has been trialed once with a class of postgraduate students. As the results and feedback from the postgraduate students was very positive a second implementation with a class of post graduates was conducted and the results are presented here. The CPSA, as the name implies, was developed for assessment purposes. However, the writers have found that it is an ideal tool for teaching professional skills and both undergraduate and postgraduate students alike considered it very beneficial.

\section{LITERATURE REVIEW}

UNESCO warned, in their report Skills Gaps Throughout the World (Aring, 2012) that employee skill deficiencies constrain the ability of companies to mature, innovate, produce timely products and services, meet criteria for quality and environmental, cultural and societal requirements in countries where they operate. The report also identified the lack of available talent and a trained workforce in the Middle East as the greatest threat to sustainable human and other resource development. The most significant gaps in skills were classified into four categories: technical, cultural, interpersonal, and intrapersonal.

The 2016 Abu Dhabi Competitiveness Report (Abu Dhabi Department of Economic Development, 2016) considers human capital as a critical input for national competitiveness: "Enhancing the match between education outputs and job market requirements and improving workforce skills are expected to carry the Emirate to competitiveness champion levels in human capital'(p. 27). The report underscores the need to increase the number of students graduating from STEM fields, as well as graduates and employees with strong professional skills to assume greater responsibilities as managers and leaders.

The 2014 Arab Knowledge Report (United Nations Development Programme Regional Bureau for Arab States and the Mohammed bin Rashid Al Maktoum Foundation, 2014) details the knowledge and capabilities of a representative sample of Emirati undergraduates in their final academic year in all UAE public universities. The UAE, as is the case with other countries in the region, has not achieved its goal to develop citizens who have the ability to generate knowledge products, such as foundational research that result in patents. The report recommends that if the UAE desires its nationals to produce, employ, transfer and localize knowledge in science and technology research and implementation, then it must provide greater motivation for youth to pursue STEM related educational and occupational trajectories.

In 2013, UAE employers said they valued professional skills more than specific disciplinary skills(Arab Thought Foundation, 2013), echoing global and regional quality assurance organization requirements such as ABET - the international accrediting body for technical education, AACSB Association to Advance Collegiate Schools of Business, the United States' higher education accrediting body Middle States (MSCHE) that also accredits internationally, the National Council for Accreditation of Teacher Education (NCATE/CAEP), the UAE's Commission of Academic Accreditation (CAA) and the Qualification Framework Emirates (QFE).

As mentioned earlier professional skills are challenging to assess. However, as these skills are stated learning outcomes on tertiary programs nowadays they must be taught and assessed. Not only are they required to be assessed for courses and programs but also for accreditation purposes. Various researchers have spoken about the difficulty of measuring both technical and non-technical skills (Hart Research Associates, 2015; Lattuca, Terenzini, Knight, \& Ro, 2014; OECD, 2015). Reasons are that the pedagogical methodology and measurement instruments are limited and at an early stage of development, and that each of the professional skills outcomes requires conceptual elaboration for 
the practical purpose of assessment design and implementation. Another reason according to Felder (2012) is that many faculty members do not have experience in assessment of non-technical skills. They may not have been assessed in this when they were students and they may not have been educated in how to assess these skills.

A number of different approaches has been published on evaluation of professional skills. Al-Bahi, Taha and Turkmen (2013) describe the use of student internships. An advantage of student internships is that all of the skills can be examined as students should demonstrate them over the period of the work experience. However, a major disadvantage is the lack of standardization as typically the evaluation is done by the employer and the individual faculty member supervising the student. Lopez, Cruz, Sanchez and Fernandez (2011) discuss a more traditional method - the take-home written exam. While this type of assessment can test the students' understanding of the theory of the professional skills it does not test the actual application of the skills. The written test does give students time to reflect upon their use of the skills, but it does not reliably test their abilities in the skills. Another form of assessment is through the use of portfolios (Christy, 2013; Richerson, McAteer, Spencer, \& Scheibler, 2007). Portfolios contain written reflections on the students' application of the skills, but again it is not a direct assessment of the skills.

Many of the assessment methods examine each of the skills on their own separate from each other. In the real world these skills are related to each other and therefore it is best to evaluate them with tools than can measure them concurrently. Also, many of the methods are indirect rather than direct forms of assessment. An indirect method is, for example, one that is based on perceptions, whereas a direct method is based on actual performance. An indirect method is not adequate for a reliable measurement of learning outcomes. Additionally, a disadvantage with some of these approaches is that that can be cumbersome and time consuming to implement. Douglas and Purzer, (2015) point out that poor approaches to assessment can actually be harmful to programs because data that is incorrect may be used in decision making for program or curricula change.

A method was developed in the USA by Ater Kranov and her team to assess all the ABET professional skills for the engineering discipline. (Ater Kranov et al., 2011). It was the first published method to assess all the ABET professional skills simultaneously and directly. The method, known as the Engineering Professional Skills Assessment (EPSA), is essentially a discussion-based performance task which requires students to demonstrate their ability in the skills. Students are given a scenario to read about a complex ill-defined issue. They are then required to discuss the issue among themselves in teams of about five students for 45 minutes. The scenario is designed in a specific manner with a set of specific prompts so that the students demonstrate their ability in each of the skills. The discussion is recorded and subsequently rated by a faculty team using the EPSA rubric.

Researchers have shown that performance assessment is an effective way to measure students' knowledge and skills (Brualdi, 1998; Johnson, Penny \& Gordon, 2009). Performance assessments are based on authentic issues and engage students, and they are designed to address learning outcomes that are inter-related. The EPSA incorporates the typical aspects of a performance assessment - a task, the student performance of the task, and a criterion referenced rubric to evaluate the quality of the performance (Ater Kranov et al., 2011). The method was shown to be valid and reliable.

The EPSA method inspired the writers to develop a more comprehensive method to be used in the computing discipline and with students for whom English is a second language. While EPSA can successfully assess the skills some questioned the rigour of the approach as it is based on a 45 minutes face-to-face discussion. The writers took the idea of EPSA and developed a much more rigorous method based on a discussion board activity running for a 12-day period. This method, the CPSA, is presented in the next section. 


\section{The Computing Professional Skills Assessment}

Our international research team has developed a performance assessment, called the Computing Professional Skills Assessment (CPSA), for assessing learner attainment of professional skills necessary to computing fields i.e., computer science, information technology and information systems.

The CPSA is the sole performance assessment in the literature that can be used to both teach and assess the six non-technical skills required by ABET, the US-based world leader in accreditation of technical education programs at the tertiary level, for both course and program-level purposes. ABET's Computing Accreditation Commission (CAC) requires academic programs to show student attainment of 14 learning outcomes at the end of the curricular cycle. Six out of the 14 are the professional skills outcomes and these are shown in Table 1 using the letters assigned by ABET, i.e., b, d, $\mathrm{e}, \mathrm{f}, \mathrm{g}$. and $\mathrm{h}$ (ABET, 2015). Table 1 also shows the alignment between the ABET CAC professional skills learning outcomes and those targeted in the CPSA. The CPSA learning outcomes have been altered from ABET's versions to better fit the task involved in the assessment and to follow best practices for writing learning outcomes. For example, ABET professional skill, $\mathrm{f}$, which is communication in general, has been changed to only writing because the CPSA task is only written communication. Also, the introductory phrase, Students will be able to has been added to each learning outcome, so they read as learning outcomes rather than basic phrases (Schoepp, 2017).

Table 1. ABET CAC and CPSA learning outcomes alignment.

\begin{tabular}{|l|l|}
\hline \multicolumn{1}{|c|}{ ABET CAC } & \multicolumn{1}{|c|}{ CPSA } \\
\hline $\begin{array}{l}\text { (b) An ability to analyze a problem, and identify } \\
\text { and define the computing requirements appropri- } \\
\text { ate to its solution. }\end{array}$ & $\begin{array}{l}\text { 1-Students will be able to problem solve from a } \\
\text { computing perspective. }\end{array}$ \\
\hline $\begin{array}{l}\text { (d) An ability to function effectively on teams to } \\
\text { accomplish a common goal. }\end{array}$ & $\begin{array}{l}\text { 2-Students will be able to work together to } \\
\text { perform a specific task. }\end{array}$ \\
\hline $\begin{array}{l}\text { (e) An understanding of professional, ethical, legal, } \\
\text { security and social issues and responsibilities. }\end{array}$ & $\begin{array}{l}\text { 3-Students will be able to evaluate professional, } \\
\text { ethical, legal, security and social issues when } \\
\text { solving a problem. }\end{array}$ \\
\hline $\begin{array}{l}\text { (f) An ability to communicate effectively with a } \\
\text { range of audiences. }\end{array}$ & $\begin{array}{l}\text { 4-Students will be able to communicate profes- } \\
\text { sionally in writing. }\end{array}$ \\
\hline $\begin{array}{l}\text { (g) An ability to analyze the local and global impact } \\
\text { of computing on individuals, organizations, and } \\
\text { society. }\end{array}$ & $\begin{array}{l}\text { 5-Students will be able to analyze the local and } \\
\text { global impacts of computing. }\end{array}$ \\
\hline $\begin{array}{l}\text { (h) Recognition of the need for and an ability to } \\
\text { engage in continuing professional development. }\end{array}$ & $\begin{array}{l}\text { 6-Students will be able to recognize when they } \\
\text { need to seek further information to extend } \\
\text { their knowledge. }\end{array}$ \\
\hline
\end{tabular}

The CPSA is a team-based performance assessment where students problem-solve in an online environment to discuss, analyze and propose ways to address current complex regional technical issues. The transcripts of the discussion are subsequently rated by a calibrated faculty team using the CPSA Rubric.

Performance assessments are designed to address the more complex aspects of learning by asking students to grapple with authentic problems. A performance assessment typically has three components: (1) a task that elicits the performance; (2) the performance itself (which is the event or artifact to be assessed); and (3) a criterion-referenced instrument, such as a rubric, to measure the quality of the performance. Student or employee performance, researchers say, can best be measured by observation and through the use of an analytic measurement tool, such as a rubric. Participants in a per- 
formance assessment "demonstrate their knowledge and skills by engaging in a process and/or constructing a product" (Johnson et al., 2009).

The CPSA consists of (1) a scenarios and discussion prompts as the performance task; (2) the student team discussion as a response to the performance task (the transcript is from an online discussion board tool used by students to discuss asynchronously over a 12-day period); and (3) the CPSA Rubric as the criterion-referenced instrument to measure the quality of the student team performances of the targeted professional skills. Scenario topics include, but are not limited to cybersecurity, encryption, big data, the internet of things, and brain implants. Appendix A provides a sample scenario.

The CPSA has been iteratively developed over the past four years with amendments and refinements to improve the method and enhance validity and reliability. To read more about the establishment of the reliability and validity of the method see Schoepp, Danaher \& Ater Kranov (2017); Danaher, Schoepp, \& Ater Kranov, (2016a); Danaher, Schoepp, \& Ater Kranov (2016b).

\section{THE CONTEXT}

Zayed University, the site of this project's data collection, is one of three federal tertiary education institutions that serves Emirati nationals by preparing them to contribute to the societal and economic welfare of the nation. The university was established in 1998 as a federal, English-language medium, outcomes-based institution for Emirati nationals with gender-segregated campuses in Abu Dhabi and Dubai, serving almost 10,000 students. Nearly all undergraduate students are aged between 18 and 22 with no work experience. Thus, the university strives to deliver programs that meet international standards to ensure graduating students are prepared to contribute to and promote the social and economic wellbeing of UAE society and its knowledge economy.

The College of Technological Innovation (CTI), one of six degree-granting colleges and the home of this research project, offers computing degrees at the bachelor's and master's levels to nearly 1,000 students. Recognized for its outstanding work in establishment and implementation of universitywide learning outcomes assessment system, Zayed University is institutionally accredited by the USbased Middle States Commission on Higher Education. Two CTI Programs are accredited by ABET and, thus, are required to regularly assess student attainment of a set of technical and non-technical skills for continuous improvement purposes.

Students who need higher English language scores before matriculating participate in an intensive English language program located on site. All students must successfully complete the foundation requirements of the University College prior to entering a disciplinary college and individual academic program. The foundation program is designed to bridge the gap from secondary school. According to the OECD's Program for International Student Assessment (PISA) results from 2015, UAE students in secondary public education performed below the average in science, math and reading of all non-OECD member participating countries (OECD, 2017). From 2006-2015, their level was significantly lower in the three topic areas, with students performing less than half the mean average for other non-OECD member participating countries.

\section{METHOD}

In the Spring Semester 2017 a class of 17 Information Technology master's students participated in the activity. The class was a mix of males and females and the ages ranged from 22 to 29 . The activity was embedded as an assignment in the course which was on the subject of IT and society. The activity was conducted in two rounds as described below. Two sets of data were collected following the activity: data pertaining to the CPSA Rubric ratings and data from a survey of the students at the conclusion of the activity. The purpose of the survey is to get feedback from the students on their perceptions of the usefulness of the CPSA from a learning perspective and to solicit suggestions on possible improvements. 


\section{THE STUDENT GROUP DISCUSSION}

The student group discussion is elicited by a $1 \frac{1}{2}$ page scenario (see sample in Appendix A) about the issue, and students are provided with a list of prompts that they should consider during the discussion.. The prompts are:

1. What are the primary and secondary problems?

2. Who are the major stakeholders and what are their perspectives?

3. What are some of the major professional, ethical, legal, security and social issues?

4. What are the local and global implications of both the problem/s and possible solutions?

5. What, if any, additional information would you need to effectively address the problem $/ \mathrm{s}$ ?

6. What are the next steps that would lead to possible future solutions?

Our team has found that the CPSA is most effective when implemented in two stages (particularly for undergraduates as they have typically not participated in this type of active learning and critical thinking in a discussion environment). The first stage serves as preparation for the assessment and as learning and practice of the skills, and as an opportunity for instructor feedback.

The first stage starts with a presentation of the method and all the practical aspects of using the discussion board. This presentation takes up a full class period. Then the students in groups of 4 or 5 commence work for a 12-day period with a particular scenario. During this period the students are given instruction and guidance and frequently reminded of the aims of the activity and the expectations. For most undergraduate and graduate students, this is the first time they have participated in this type of activity. During the on-line discussion, if there is poor participation or interaction or students are off track, the instructor enters into the discussion and provides guidance. The students are expected to make about 5 or 6 substantial posts over the 12-day period. Although the instructor provides guidance the discussion is student led, so the students must generate the ideas, responses and solutions. At the completion of this round, postings are anonymized and used as an in-class teaching resource to demonstrate high and low quality responses.

The second stage is similar to the first. The students are given a different scenario and embark upon a 12-day online discussion, but this time there is no instructor intervention unless absolutely necessary. The data from this second round is used for assessment using the CPSA Rubric. To ensure participation and effort by all students, the activity is a mandatory course requirement with an appropriate weighting and grades are awarded to individuals (i.e., not team based) for course grading purposes. As all courses at Zayed University have a set of program learning outcomes as well as course learning outcomes this type of assessment gets buy-in from faculty and students as an assessment of the program learning outcomes.

\section{THE CPSA RUBRIC}

The CPSA Rubric is a task-specific analytic rubric, which means that it was designed specifically to be used as a measurement tool in conjunction with the accompanying method, which in our case is the scenario and prompts. The rubric is organized by learning outcome, with each outcome having its own set of performance indicators and descriptors on a common integer scale from 0 to 5 , labeled as 0-Missing, 1- Emerging, 2-Developing, 3-Practicing, 4-Maturing, and 5-Mastering. We chose the scale terminology to explicitly reflect the developmental nature of the skills set and to correspond approximately to study year. A 3rd year student, for example, should achieve around a 3 , a $4^{\text {th }}$ year student near graduation should achieve around a 4 and a 5 th year student (post graduate level) should achieve 5. An abbreviated version of the CPSA Rubric is shown in Appendix B. Because the CPSA is intended to be used for both course and program level assessment purposes and because group problem solving is critical to teamwork, the students are assessed as groups and not individually. Prior to assessing the discussion groups, faculty participate in a calibration (sometimes referred to as norming) process, using the consensus-estimate approach whereby evaluators must come to consensus as to what constitutes evidence of a given descriptor and score within one point difference on the scale 
(Stemler, 2004). Calibrations is crucial to the accuracy and efficacy of the implementation of a rubric (Holmes \& Oakleaf, 2013)

A rating session begins with a review of the CPSA Rubric to refresh their memories. Raters are given a printed copy of the discussion transcript for each group. Raters then begin the process of assessing groups against the specific criteria and descriptors in the rubric. When complete, raters share their scores using examples from the discussion transcript to support the assigned scores. Where there is disagreement, further examples are presented from the discussion transcript and the rubric criteria as raters work towards consensus. This approach to rating sessions follows the process recommended by the University of Hawaii Manoa's Assessment Office where consensus is developed by having raters explain their evaluations through providing examples directly from the discussion text (University of Hawaii Manoa, 2013). Because we are continually trying to enhance reliability and validity of the CPSA Rubric when it is used at undergraduate and graduate education levels, complete rater agreement is not an expectation, nor is it required, as the goal is a shared understanding for subsequent rubric improvement. Upon completion of the rating sessions, scores are recorded, and then the mean is calculated to determine the overall score by the group for each of the outcomes. A detailed discussion of rater calibration and the rating process may be found in Schoepp, K., Danaher, M. \& Ater Kranov, A. (2018).

Though consensus-based, investigating the inter-rater reliability is critical. Stemler (2004) posits that levels of agreement between raters should be $70 \%$ or greater, so this was the target for both the complete instrument and the individual outcomes. Inter-rater reliability was calculated through the simplest of methods - a simple count of cases receiving the same ratings divided by the total number of cases.

\section{RESULTS}

\section{CPSA RUBRIC SCORES}

The 17 graduate students were divided into four CPSA discussion groups with four to five members. At completion of the activity the transcripts were downloaded, labeled and organized, so that the three-person research team could begin evaluation using the CPSA Rubric. The evaluation was conducted as described above. The first stage was calibration of the team process and this was followed by the rating process. Assessment data from the rubric ratings were analyzed two ways: 1) outcome mean score and percentage of each outcome at the target of 5, and, 2) group mean score and each group's percentage of achieving the target of 5 (see Table 2).

Table 2. Attainment of CPSA learning outcomes for graduate students

\begin{tabular}{|c|c|c|c|c|c|c|c|c|}
\hline Group & CPSA1 & CPSA2 & CPSA3 & CPSA4 & CPSA5 & CPSA 6 & $\begin{array}{l}\text { Group } \\
\text { Mean }\end{array}$ & $\begin{array}{l}\text { Group } \\
\%=5\end{array}$ \\
\hline A & 5 & 5 & 5 & 5 & 4 & 4 & 4.67 & 66.67 \\
\hline B & 5 & 5 & 5 & 5 & 5 & 5 & 5.0 & 100 \\
\hline $\mathrm{C}$ & 5 & 5 & 5 & 4 & 5 & 5 & 4.83 & 83.33 \\
\hline $\mathrm{D}$ & 5 & 4 & 5 & 4 & 4 & 5 & 4.5 & 50 \\
\hline Outcome Mean & 5 & 4.75 & 5 & 4.5 & 4.5 & 4.75 & & \\
\hline Outcome $\%=5$ & 100 & 75 & 100 & 50 & 50 & 75 & & \\
\hline
\end{tabular}

Overall, outcome mean scores show that only in Outcome 1- Students will be able to problem solve from a computing perspective and Outcome 3- Students will be able to evaluate professional, ethical, legal, security and social issues when solving a problem were all of the groups able to attain the graduate target. These are clearly areas of strength for this cohort. The two weakest outcomes were 4-Students will be able to communicate professionally in writing and 5-Students will be able to analyze the local and global impacts of computing. This meant that only $50 \%$ of the groups achieved a 5 even though they were quite close having scored 4. 
Nonetheless, if the program were looking for areas to improve, these would be the two outcomes of concern. In terms of how each of the discussion groups performed, only Group A achieved the target of 5 on all six outcomes, while Group D was able to reach a 5 only $50 \%$ of the time. Of particular interest in this data set is that never once did a group score below 4 as had occurred in an earlier round with graduate students (Schoepp, Danaher, \& Ater Kranov, 2017).

\section{SURVEYRESULTS}

For more recent runs of the CPSA we have asked students to complete an 11-item online survey embedded directly into the learning management system. The purpose of the survey is to gauge student perceptions towards the usefulness of the CPSA from a learning perspective and to provide insights into how the activity could be improved. Students are provided with eight Likert scale items and three open-ended items to which they can respond. The Likert scale items have been adapted from the Australian Course Experience Questionnaire (Graduate Careers Australia, n.d.) in that the word "course" has been changed to "activity" to make it clear the survey is specific to the CPSA. Student participation is voluntary and submissions are anonymous. No results are directly shared with students, but conversations about the activity do occur throughout the course.

All 17 graduate students answered all Likert scale survey items. This provided students the opportunity to share their perceptions about the degree to which participation in the CPSA helped them to attain professional skills learning outcomes. Students rated each of the items either 5- Strongly Agree, 4- Agree, 3- Neither Agree nor Disagree, 2- Disagree, or 1- Strongly Disagree. In Table 3 the eight items have been listed from highest to lowest according to the mean score. Other measures in the table include the standard deviation to provide some insights into the grouping of the scores and the dichotomous percentage which shows the percentage of students who either recorded SA or A with the statements- this is a quick and simple measure to show where strengths or weaknesses in the method may exist. Given that mean scores ranged from 4.88 to 4.59 , it is clear that students strongly agree that the CPSA helped their learning. Furthermore, in only three cases, was there not complete consensus of SA or A for the dichotomous measure. Two of the three highest rated items, The activity belped to develop my ability to analyze problems (4.88 mean) and As a result of the activity, I feel more confident about tackling unfamiliar problems (4.82 mean), pertain directly to problems, so problem analysis and confidence are especially strong from the student perspective. When it came to the two lowest rated items which were still very highly rated, The activity helped to develop my problem-solving skills (4.65 mean) and The activity helped to improve my skills in written communication (4.59mean), it is interesting to note that they were two of the three items without a perfect 100\% dichotomous score and that one was related to problem-solving. It appears as though confidence towards understanding a problem and the ability to analyze a problem are exceptionally strong, but the actual ability to solve the problem is a little less so.

In addition to the eight Likert scale items, participants also responded to three open-ended questions. Participants were asked to share what they liked, disliked, and would like to change about the CPSA activity. Results from this section of the survey were also overwhelmingly positive and further demonstrated the efficacy of this activity with graduate students.

In response to the first question about what they liked, the emergent themes were related to a discussion board as a safe environment, thinking critically and learning from different perspectives, and general praise for the activity. One of the purported benefits of an asynchronous discussion is that it can serve as a safe environment for those participants shy or unwilling to speak out in a face-to-face discussion (Zhou, 2015). One participant noted that it provided the opportunity to think about and discuss the topic freely within this "safe environment". Another student shared that for those "who find it hard to talk in front of an audience, this activity really helped them speak up about their ideas without feeling any discomfort". Students also recognized that they were being forced to think critically and view things from multiple perspectives. One participant stated that it helped students "understand the concepts better, especially [being] able to view the whole picture", and another reiterat- 
ed that they learnt things "in deep details and from different perspectives". The constructs of critical thinking and diverse perspectives were constantly repeated, and it was clear that they appreciated the opportunity to share thought-out ideas over a sustained period of time. Finally, a number of students wrote glowing comments about the activity in general stating that "it is a very helpful technique, and I would like to see many activities like this", while another stated that "it is one of the best activities we had during this program [and] I hope to get more of them in the future".

Table 3. Survey Item Responses

\begin{tabular}{|l|c|c|c|}
\hline \multicolumn{1}{|c|}{ Items } & Mean & $\begin{array}{c}\text { Standard } \\
\text { Deviation }\end{array}$ & $\begin{array}{c}\text { Dichotomous } \\
\%\end{array}$ \\
\hline $\begin{array}{l}\text { The activity helped to develop my ability to analyse } \\
\text { problems. }\end{array}$ & 4.88 & .33 & 100 \\
\hline $\begin{array}{l}\text { As a result of the activity, I feel more confident about } \\
\text { tackling unfamiliar problems. }\end{array}$ & 4.82 & .39 & 100 \\
\hline $\begin{array}{l}\text { The activity helped me to develop my understanding } \\
\text { of ethical, legal and social issues. }\end{array}$ & 4.82 & .39 & 100 \\
\hline $\begin{array}{l}\text { The activity helped me to recognize the limits of my } \\
\text { knowledge and the need to continue to learn more. }\end{array}$ & 4.76 & .56 & 94.12 \\
\hline $\begin{array}{l}\text { The activity helped me develop my ability to work as } \\
\text { a team member. }\end{array}$ & 4.71 & .47 & 100 \\
\hline $\begin{array}{l}\text { The activity helped me to develop the ability to ana- } \\
\text { lyze the impact of computing on the world. }\end{array}$ & 4.71 & .47 & 100 \\
\hline $\begin{array}{l}\text { The activity helped to develop my problem-solving } \\
\text { skills. }\end{array}$ & 4.65 & .61 & 94.12 \\
\hline $\begin{array}{l}\text { The activity helped to improve my skills in written } \\
\text { communication. }\end{array}$ & 4.59 & .62 & 94.12 \\
\hline
\end{tabular}

Given the positive nature of the responses, there was not nearly the volume of feedback from the questions pertaining to what they disliked and would like to change about the activity. Though the majority of respondents stated that there was nothing they disliked about the activity, some students noted that the expectation of daily engagement was challenging. Other critiques had to do with group dynamics. A student stated that "some people were not as active as you would want them to be" which caused them to just repeat "the same thing over and over again". In a similar manner, another participant felt that keeping the group on task to complete the activity was a challenge because some group members wrote "about only one aspect of the ... issue". Of course, keeping a group on task was one of the areas assessed in the CPSA as this can be a challenge when working with others both in synchronous and asynchronous time. In terms of suggested changes, comments centered around timing, whether it be more time or less time. For example, one student believed "it would be great" if each discussion lasted for only 7 days, but another wanted "more time", so there was no consistency with this theme.

\section{DISCUSSION}

Previous studies by this research team established that the CPSA is appropriate, reliable, and valid for assessment of undergraduate student group attainment of the targeted skills. For example, in an earlier study using the CPSA the research team had set a target level for third year of the undergraduate program at $\geq 3$ - Practicing, and results showed this to be an accurate expectation as undergraduates 
scored between 1 and 4, never achieving a 5 (Danaher, Schoepp, \& Ater Kranov, 2016b). Furthermore, of the 42 total sores assigned, $83 \%(35 / 42)$ were either 2 , 3 , or 4 .

Given that we designed our rubric on the basis that graduate student groups should achieve around a score of 5-Mastering, our findings here suggest that the upper end of the CPSA Rubric scale is accurate. Graduate student groups in this study achieved mean scores ranging from 4.5 to 5.0, meaning that they were very close to achieving exactly what is desired of them. Moreover, for only two outcomes, Outcome 4-Students will be able to communicate professionally in writing and Outcome 5-Students will be able to analyze the local and global impacts of computing, did more than one group not achieve a score of 5. A previous CPSA study with graduate students found that $54 \%(13 / 24)$ of total scores assigned were at the mastery level of 5 , and in only three instances did a rating fall below a 4 (Schoepp, Danaher, \& Ater Kranov, 2017). A shortcoming of the current CPSA Rubric when used at postgraduate level is that the scale ends at 5-Mastering and that the 5-Mastering descriptors are not fine-grained enough to provide specific information regarding strengths and areas for improvement. At present, the rubric perhaps would be best used to collect baseline data from entering master's degree students. In the future the scale can be expanded beyond level 5-Mastering so as to provide more achievement levels for the postgraduates. That said, findings from this study and previous studies suggest that the CPSA Rubric, when used by a calibrated evaluation team, can clearly differentiate between undergraduate and graduate students.

As mentioned, graduate student groups performed below expectations only for Outcome 4-Students will be able to communicate professionally in writing and Outcome 5-Students will be able to analyze the local and global impacts of computing as minor areas of weakness. As students are non-native English speakers studying in a technical program, it is not surprising that writing is an area for improvement. One of the ways to improve this weakness is to make courses and the program more writing intensive. Even participation in online discussion boards has shown to increase writing proficiency (Picciano, 2002). Employers need employees who can communicate effectively and scored communication tasks help to achieve this outcome (British Council, 2013). With regards to the ability to analyze the impact of computing both locally and globally, it is imperative that students are provided with opportunities to consider and solve problems with both local and global impact throughout their course of study. Most off-the-shelf course resources do not mention the UAE, while the relatively small population of the UAE demands that students look beyond their borders to effectively analyze computing issues on a broader scale. Both areas of weakness need to be addressed if the UAE is to achieve their human capital goals and establish itself as a globally competitive market economy.

The survey results show that students recognize the key role the CPSA plays in fostering their attainment of the professional skills learning outcomes. All students thought that participation in the CPSA helped them learn. In fact, these results were far more positive than those from the undergraduate students (Danaher, Schoepp, \& Ater Kranov, 2016a). Given the maturity and work experience of graduate students over undergraduate students, this makes these results all the more meaningful. The other aspect of the survey comes from the three open-ended questions. Students recognized that the discussion board was requiring them to think critically, examine multiple perspectives, and integrate or argue against ideas of others. These are some of the skills that Anderson, Archer, and Garrison, (2000) have shown to be an outcome of a well-structured asynchronous discussion.

\section{CONCLUSION}

The CPSA is the first published method that can assess the six professional skills learning outcomes prescribed by ABET simultaneously in the computing discipline. Compared with other assessment approaches this method has many advantages: it is a direct method of measurement, it is a rigorous method and it assesses all these interrelated skills concurrently.

Results from previous implementations of the CPSA that have included over 400 undergraduate students (Danaher, Schoepp, \& Ater Kranov, 2016a, 2016b; Schoepp, Danaher \& Ater Kranov, 2017;) 
demonstrate that it can accurately and consistently elicit and measure the targeted computing professional skills for Emirati non-native speakers of English for both course and program continuous improvement. The top level of the CPSA Rubric is set at postgraduate level performance (which final year students that demonstrate excellent abilities may achieve) and in this study the method has been trialed with postgraduates. Though our sample size of only 17 students was small the results have shown that the scale is accurate and well- calibrated as the students generally performed at the top level - Mastering. Further, this corroborates a prior study (Schoepp, Danaher, \& Ater Kranov, 2017) with a similar small sample of postgraduate students where the students, though not performing overall as well as those in the current study, generally performed at or near the top of the scale.

Though originally designed for assessment it became clear during early rounds of implementation that it was an ideal method for teaching and learning the skills as well. Surveys have been conducted with the students on their perceptions of the benefits to their learning and almost all students were very positive in their response. The postgraduate students in this study were particularly impressed by the method and some wrote glowing comments about the benefits and that they hoped to see more learning activities like this.

The CPSA method can be adapted to other disciplines. The rubric has been developed for computing, but it could be easily modified for other disciplines. The topics of the scenarios are not so important as it is generic skills that are being assessed. While our scenarios have an information technology bias, they could be used as they are for related disciplines or new scenarios could be written following our scenario creation guidelines. As courses nowadays typically have a set of program learning outcomes as well as course learning outcomes this type of assessment gets buy-in from faculty and students as an assessment of the program learning outcomes.

As we move forward in our research we have plans to expand the rubric beyond level 5-Mastering so as to have more achievement levels for postgraduates. We also intend developing a rubric that could be used by employers for internship students and for employee education and training.

\section{ACKNOWLEDGEMENT}

This research has been funded by a grant from Zayed University's Research Incentive Fund and a grant from the Abu Dhabi Education Council's Award for Research Excellence.

\section{REFERENCES}

Accreditation Board for Engineering and Technology (ABET), (2015). Criteria for accrediting computing programs. Retrieved from https://www.abet.org/wp-content/uploads/2016/09/C001-16-17-CAC-Criteria-10-1515.pdf

Abu Dhabi Department of Economic Development, (2016). Abu Dhabi competitiveness report 2016. Retrieved from https://ded.abudhabi.ae/en/ded-center/Competitiveness-Office-of-Abu-Dhabi/reports-andstudies/Abu\%20Dhabi\%20Competitive\%20Report English 1410.pdf

Al-Bahi, A. M., Taha, M. A., \& Turkmen, N. (2013). Teaching and assessing engineering professional skills. International Journal of Engineering Pedagogy, 3(3), 13-20. https://doi.org/10.3991/ijep.v3iS3.2728

Anderson, T., Archer, W., \& Garrison, D. R. (2000). Critical inquiry in a text-based environment: Computer conferencing in higher education model. The Internet and Higher Education, 2(2-3), 87-105.

Arab Thought Foundation. (2013). Enabling job creation in the Arab world: A role for regional integration. Retrieved from https://www.pwc.com/m1/en/publications/enabling-job-creation-in-arab-world.pdf

Aring, M. (2012). Skills gaps throughout the world: An analysis for UNESCO global monitoring. Retrieved from http://unesdoc.unesco.org/images/0021/002178/217874e.pdf

Ater Kranov, A., Zhang, M., Beyerlein, S. W., McCormack, J., Pedrow, P. D., \& Schmeckpeper, E. R. (2011). A direct method for teaching and measuring engineering professional skills: A validity study. In 2011 Ameri- 
can Society for Engineering Education Annual Conference, Vancouver, Canada. Retrieved from http://www.asee.org/public/conferences/1/papers/775/view

Ater Kranov, A., \& Khalaf, K. (2016). Investigating the employment gap: What employers want from engineering graduates. In 2016 IEEE Global Engineering Education Conference (EDUCON), Abu Dhabi, 2016, pp. 1198-1201. https://doi.org/10.1109/EDUCON.2016.7474708

British Council. (2013). Culture at work: The value of intercultural skills in the workplace. Retrieved from https://www.britishcouncil.org/sites/default/files/culture-at-work-report-v2.pdf

Brualdi, A. C. (1998). Implementing performance assessment in the classroom. Practical Assessment, Research \& Evaluation, 6(2). Retrieved from http://PAREonline.net/getvn.asp?v $=6 \& n=2$

Christy, A. D. (2013). Student portfolios for assessing ABET a-k outcomes. In Proceedings of the 2013 ASEE North Central Section Conference. Retrieved from https://www.researchgate.net/publication/259972436 Student portfolios for assessing ABET a$\underline{\mathrm{k} \text { outcomes }}$

Danaher, M., Schoepp, K., \& Ater Kranov, A. (2016a). The Computing Professional Skills Assessment: An innovative method for assessing ABET's student outcomes. In Proceedings of EDUCON 2016, April 2016, Abu Dhabi, UAE. Retrieved from http://ieeexplore.ieee.org/document/7474529/

Danaher, M., Schoepp, K., \& Ater Kranov, A. (2016b). A new approach for assessing ABET's professional skills. World Transactions on Engineering and Technology Education, 14(3), 355-360, Retrieved from http://www.wiete.com.au/journals/WTE\&TE/Pages/Vol.14,\%20No.3\%20(2016)/04-Danaher-M.pdf

Douglas, K. A., \& Purzer, S. (2015). Validity: Meaning and relevancy in assessment for engineering education research. Journal of Engineering Education, 104(2), 108-118. https://doi.org/10.1002/jee.20070

Felder, R. M. (2012). Engineering education: A tale of two paradigms. In B. McCabe, M. Pantazidou, \& D. Phillips (Eds.), Shaking the foundations of geo-engineering education, (pp. 9-14). Leiden, Netherlands: CRC Press. https://doi.org/10.1201/b15096-4

Graduate Careers Australia. (n.d.). Australian course experience questionnaire (CEQ). Retrieved from http://www.graduatecareers.com.au/research/surveys/australiangraduatesurvey/

Hart Research Associates. (2015). Falling short? College learning and career success. Retrieved from https://www.aacu.org/sites/default/files/files/LEAP/2015employerstudentsurvey.pdf

Holmes, C., \& Oakleaf, M. (2013). The official (and unofficial) rules for norming rubrics successfully. Journal of Academic Librarianship 39(6), 599- 602. https://doi.org/10.1016/j.acalib.2013.09.001

Johnson, R. L, Penny, A. J., \& Gordon, B. (2009). Assessing performance: Designing, scoring, and validating performance. The Guilford Press, New York.

Lattuca, L., Terenzini, P., Knight, D., \& Ro, H. K. (2014). 2020 vision: Progress in preparing the engineer of the future. Retrieved from https://deepblue.lib.umich.edu/bitstream/handle/2027.42/107462/2020\%20Vision\%20FINAL.pdf?sequ ence $=5 \&$ is Allowed $=\mathrm{y}$

Lopez, D., Cruz, J. L., Sanchez, F., \& Fernandez, A. (2011). A take-home exam to assess professional skills. Proceedings of the 41st ASEE/IEEE Frontiers in Education Conference. Retrieved from http:/ / citeseerx.ist.psu.edu/viewdoc/download?doi=10.1.1.301.9792\&rep=rep1\&type $=$ pdf

Organization for Economic Cooperation and Development (OECD). (2015). Better skills, better jobs, better lives: A strategic approach to education and skills policies for the United Arab Emirates.: OECD Publishing, Paris, France. Retrieved from http://www.oecd.org/countries/unitedarabemirates/A-Strategic-Approach-to-Educationand $\% 20$ Skills-Policies-for-the-United-Arab-Emirates.pdf

Organization for Economic Cooperation and Development (OECD). (2017). United Arab Emirates student performance (PIS A 2015). Retrieved from http://gpseducation.oecd.org/CountryProfile?primaryCountry=ARE\&treshold=10\&topic=PI

Picciano, A. G. (2002). Beyond student perceptions: Issues of interaction, presence, and performance in an online course. Journal of Asynchronous Learning Networks, 6(1), 21-40. 
Effective Evaluation of the Non-Technical Skills in the Computing Discipline

Richerson, S., McAteer, K., Spencer, M., \& Scheibler, S. (2007). A portfolio approach to learning professional skills. Proceedings from the Frontiers in Education Conference, October 2007, Milwaukee, USA, (pp. F3B-1). https://doi.org/10.1109/FIE.2007.4417802

Schoepp, K. (2017): The state of course learning outcomes at leading universities. Studies in Higher Education, 113. https://doi.org/10.1080/03075079.2017.1392500

Schoepp, K., Danaher, M., \& Ater Kranov, A. (2017). The Computing Professional Skills Assessment utilized with graduate students. In Proceedings of IEEE EDUCON 2017 Global Engineering Education Conference, April 2017, Athens, Greece.

Schoepp, K., Danaher, M. \& Ater Kranov, A. (2018). An effective rubric norming process. Practical Assessment, Research and Evaluation (PARE), 23(11). https://pareonline.net/getvn.asp? $\mathrm{v}=23 \& \mathrm{n}=11$

Shuman, L. J., Besterfield-Sacre, M., \& McGourty, J. (2005). The ABET “Professional Skills"- Can they be taught? Can they be assessed? Journal of Engineering Education, 94(1), 41- 55. https://doi.org/10.1002/j.2168-9830.2005.tb00828.x

Stemler, S. E. (2004). A comparison of consensus, consistency, and measurement approaches to estimating interrater reliability. Practical Assessment, Research \& Evaluation, 9(4). Retrieved from http://pareonline.net/getvn.asp?v=9\&n=4

United Arab Emirates, UAE. (2010). UAE Vision 2021. Retrieved from https://www.vision2021.ae/en/ourvision

United Nations Development Programme Regional Bureau for Arab States and the Mohammed bin Rashid Al Maktoum Foundation. (2014). The 2014 Arab Knowledge Report: UAE. Retrieved from http://www.arabstates.undp.org/content/rbas/en/home/library/huma development/arab-knowledgereport-2014.html

University of Hawaii Manoa. (2013). Creating and using rubrics. Retrieved from http://manoa.hawaii.edu/assessment/howto/rubrics.htm

Zhou, H. (2015). A systematic review of empirical studies on participants' interactions in internet- mediated discussion boards as a course component in formal higher education settings. Online Learning Journal, 19(3). Retrieved from https://doi.org/10.24059/olj.v19i3.675

\section{APPENDICES}

\section{APPENDIX A: SAMPLE SCENARIO ON E-WASTE}

Meet Xiao Zhang. This forty-year-old former farmer and resident of Giuyu, a small city in south eastern China, has never used a computer, photocopier or iPhone. In spite of this, Xiao has quite possibly interacted with every single high-tech component in existence every day for the last six years. His job? Scavenging electronic parts and melting lead solder off circuit boards in what may be the largest E-waste dump on earth. In exchange, he makes less than three US dollars (less than 10 AED) a day. Xiao and about 100,000 other workers in Giuyu scavenge E-waste for recoverable materials, earning a wage five times more than they would earn as a farmer or laborer.

The Guiyu operation is not legal in China, but the venture is so profitable that it continues to thrive. E-waste is sold to processors who are the lowest bidders. In 2014, 41 million tons, 90\%- of the world's E-waste, was illegally exported or dumped in Ghana, Nigeria, China, Pakistan, India or Vietnam. Exporting of E-waste to the developing world has been illegal since 2000. Despite this ban, E-waste is still shipped undercover, as "second-hand" goods.

Electric and electronic component waste, referred to in industry by the acronym WEEE and by the general public as E-waste, is composed largely of materials from computers, phones, tablets, laptops, MP3 players, televisions, monitors and printers that have been disposed of by consumers. Twenty to fifty million metric tons of E-waste are generated globally each year. Only 10-18\% of E-waste is recycled and represents only $2 \%$ of trash in US landfills, but constitutes $70 \%$ of the overall toxic waste. 
The amount of E-waste is growing 5\% annually worldwide. In 2011 alone, Americans disposed of about 130,000 computers and 300,000 cell phones every day.

There is substantial economic rationale to recover or refurbish electronic products. When a reuse opportunity is not identified, E-waste can be processed to reclaim valuable materials. When processed properly, materials are recovered, hazardous waste is treated and expensive and potentially damaging mining operations to acquire additional raw materials can be avoided. When processed improperly, E-waste has negative environmental and health impacts. To make metal parts recoverable for re-use, plastics must be burned which, in turn, release toxic smoke. Metals are separated with an acid wash, which is then typically seeps into the ground or water. E-waste that cannot be separated is buried in the ground, allowing metals such as lead, mercury and copper, as well as other minerals and chemicals, pollute land and water.

The health effects on Giuyu residents are significant: about $88 \%$ of the E-waste workers have neurological, respiratory, or digestive abnormalities. Children have $50 \%$ more lead in their blood than typical values. Acid present in tap-water caused extreme tooth deterioration, before the city began piping in drinking water from $40 \mathrm{~km}$ away. The land outside of the city has extremely high levels of lead, as does the breast milk of nursing women. High levels of elements such as copper, cadmium and flame-retardant chemicals can also be found in the air, water systems and land. These elements are known to attack the nervous system, kidneys and liver and increase the risk of cancer.

Recycling of E-waste in the Middle East Gulf region is well below the global average. However, governments in the region have started to develop regulations. In Qatar, where each inhabitant produced $68.03 \mathrm{~kg}$ of E-waste in 2012, rules for both shops and customers were put in place approximately 5 years ago to reduce the numbers. E-waste figures for the UAE from the same year $(29.28 \mathrm{~kg}$ per person) were below the world average ( $43 \mathrm{~kg}$ per person). The UAE has only recently began to regulate E-waste. It is unclear whether the UAE government, electronics outlets or consumers will pay to develop and sustain recycling in the country.

There are signs that consumers and companies are becoming more aware of the growing E-waste problem. Apple's decision not to include a headphone socket on the iPhone 7 was met with negative reactions and over 300,000 people signed a petition complaining that this move forces consumers to produce more e-waste as old headphones are discarded. Hewlett-Packard and the Kenyan government are building a recycling network which provides equipment and training to the urban poor who make a living from recycling, as well as a fair price for the parts and materials they produce.

\section{Sources}

Debusman, B. (2015, Feb 11). New regulations are coming up to deal with e-waste. Khaleej Times. Retrieved from http://www.khaleejtimes.com/nation/general/new-regulations-are-coming-up-to-deal-with-e-waste

Fitzgerald, G. (2015). Future Scenarios of E-Waste in China. In Unmaking Waste Conference Proceedings Adelaide, SA: Zero Waste SA Research Centre for Sustainable Design and Behaviour, 2015 (pp. 443-456). Retrieved from http://unmakingwaste2015.org/

Fox, N. (2014, May 15). Hewlett-Packard introduces large-scale e-waste recycling in Africa. The Guardian. Retrieved from https://www.theguardian.com/sustainable-business/sustainability-case-studies-hewlettpackard-ewaste-recycling-africa

Lund, B. R. (2016). Issues with e-waste: Applying the tenets of the new environmental governance. Journal of Applied Security Research, 11(3), 362-384. https://doi.org/10.1080/19361610.2016.1178556

Wynn Kirby, P., \& Lora-Wainright, A. (2015). Exporting harm, scavenging value: transnational circuits of ewaste between Japan, China and beyond. Area, 47(1), 40-47. https://doi.org/10.1111/area.12169 


\section{APPENDIX B: THE COMPUTING PROFESSIONAL SKILLS ASSESSMENT (CPSA) RUBRIC}

\begin{tabular}{|c|c|c|c|c|c|}
\hline 0 - Missing & 1 - Emerging & 2- Developing & 3 - Practicing & 4 - Maturing & 5 - Mastering \\
\hline $\begin{array}{l}\text { Students do } \\
\text { not identify the } \\
\text { problem(s) in } \\
\text { the scenario. }\end{array}$ & \multicolumn{2}{|c|}{$\begin{array}{l}\text { Students begin to define the prob- } \\
\text { lem(s). Potential solutions may be } \\
\text { general and/or naive. }\end{array}$} & \multicolumn{2}{|c|}{$\begin{array}{l}\text { Students are generally successful in } \\
\text { defining primary and secondary prob- } \\
\text { lems with reasonable accuracy and } \\
\text { with justification. There is evidence } \\
\text { that they have begun to formulate } \\
\text { potential solutions from a computing } \\
\text { perspective. }\end{array}$} & $\begin{array}{l}\text { Students convincingly and accurately } \\
\text { define the primary and secondary } \\
\text { problems, providing justification. } \\
\text { They suggest detailed and viable po- } \\
\text { tential solutions from a computing } \\
\text { perspective. }\end{array}$ \\
\hline $\begin{array}{l}\text { Students do } \\
\text { not identify } \\
\text { stakeholders. }\end{array}$ & \multicolumn{2}{|c|}{$\begin{array}{l}\text { Students identify the most obvious } \\
\text { stakeholders. Students may state } \\
\text { stakeholder perspectives in an inac- } \\
\text { curate or limited way. }\end{array}$} & \multicolumn{2}{|c|}{$\begin{array}{l}\text { Students explain the perspectives of } \\
\text { major relevant stakeholders and con- } \\
\text { vey these with reasonable accuracy. }\end{array}$} & $\begin{array}{l}\text { Students thoughtfully consider per- } \\
\text { spectives of diverse relevant stake- } \\
\text { holders and articulate these with } \\
\text { clarity and accuracy. }\end{array}$ \\
\hline
\end{tabular}

\begin{tabular}{|c|c|c|c|c|c|}
\hline 0 - Missing & 1 - Emerging & 2 -Developing & 3 - Practicing & 4 - Maturing & Mast \\
\hline $\begin{array}{l}\text { Student discus- } \\
\text { sion is not } \\
\text { guided by the } \\
\text { prompts. }\end{array}$ & \multicolumn{2}{|c|}{$\begin{array}{l}\text { Students get off task. They may be } \\
\text { unaware that they have gotten off } \\
\text { task or may work to get back on task } \\
\text { but unsuccessfully. }\end{array}$} & \multicolumn{2}{|c|}{$\begin{array}{l}\text { Students recognize when they get off } \\
\text { task and work to get back on task. }\end{array}$} & $\begin{array}{l}\text { Student discussion is closely aligned to } \\
\text { the entire set of prompts. } \\
\text { Students plan their discussion accord- } \\
\text { ing to the prompts in order to ensure } \\
\text { completion and thorough considera- } \\
\text { tion. }\end{array}$ \\
\hline $\begin{array}{l}\text { Students do } \\
\text { not } \\
\text { acknowledge } \\
\text { or encourage } \\
\text { participation of } \\
\text { others. }\end{array}$ & \multicolumn{2}{|c|}{$\begin{array}{l}\text { Students may pose individual opin- } \\
\text { ions without linking to what others } \\
\text { say. }\end{array}$} & $\begin{array}{l}\text { Students acknowl } \\
\text { clarify and/or crit } \\
\text { ideas with some s } \\
\text { Students encouras } \\
\text { others to come to }\end{array}$ & $\begin{array}{l}\text {, build on, } \\
\text { and others } \\
\text { ess. } \\
\text { articipation of } \\
\text { sensus. }\end{array}$ & $\begin{array}{l}\text { Students clearly encourage participa- } \\
\text { tion from all group members, generate } \\
\text { ideas together, actively help each } \\
\text { other, and clarify and/or critique each } \\
\text { other's ideas. }\end{array}$ \\
\hline 0 - Missing & 1 - Emerging & 2 - Developing & 3 - Practicing & 4 - Maturing & 5 - Mastering \\
\hline $\begin{array}{l}\text { Students do } \\
\text { not identify } \\
\text { ethical, legal, } \\
\text { and security } \\
\text { considerations. }\end{array}$ & \multicolumn{2}{|c|}{$\begin{array}{l}\text { Students give passing attention to } \\
\text { related ethical considerations and/or } \\
\text { may describe only the most obvious } \\
\text { ethical considerations. }\end{array}$} & \multicolumn{2}{|c|}{$\begin{array}{l}\text { Students identify relevant ethical, } \\
\text { legal, and security considerations in } \\
\text { context of the problem(s). }\end{array}$} & $\begin{array}{l}\text { Students clearly articulate relevant } \\
\text { ethical, legal, and security considera- } \\
\text { tions and evaluate them in the context } \\
\text { of the problem(s). }\end{array}$ \\
\hline \multicolumn{6}{|c|}{ CPSA 4. Students will be able to communicate professionally in writing. } \\
\hline 0 - Missing & 1 - Emerging & 2-Developing & 3 - Practicing & 4 - Maturing & 5 - Mas \\
\hline $\begin{array}{l}\text { Students are } \\
\text { unable to write } \\
\text { in an accurate } \\
\text { manner. }\end{array}$ & \multicolumn{2}{|c|}{$\begin{array}{l}\text { Student errors in grammar, punctua- } \\
\text { tion, and spelling at times impedes } \\
\text { the effectiveness of communication. }\end{array}$} & \multicolumn{2}{|c|}{$\begin{array}{l}\text { Students have few errors in grammar, } \\
\text { punctuation, and spelling, so effective } \\
\text { communication is seldomly impeded. }\end{array}$} & $\begin{array}{l}\text { Students write clearly and have no } \\
\text { discernable grammar, punctuation, or } \\
\text { spelling errors. }\end{array}$ \\
\hline $\begin{array}{l}\text { Students do } \\
\text { not demon- } \\
\text { strate a profes- } \\
\text { sional vocabu- } \\
\text { lary. }\end{array}$ & \multicolumn{2}{|c|}{$\begin{array}{l}\text { Students inconsistently demonstrate } \\
\text { a professional vocabulary. }\end{array}$} & \multicolumn{2}{|c|}{$\begin{array}{l}\text { At times students demonstrate the } \\
\text { vocabulary expected of a computing } \\
\text { professional. }\end{array}$} & $\begin{array}{l}\text { Students consistently demonstrate the } \\
\text { vocabulary expected of a computing } \\
\text { professional. }\end{array}$ \\
\hline 0 - Missing & 1 - Emerging & 2 -Developing & 3 - Practicing & 4 - Maturing & 5 - Mastering \\
\hline $\begin{array}{l}\text { Students do } \\
\text { not consider } \\
\text { either the local } \\
\text { or global im- } \\
\text { pacts of com- } \\
\text { puting on } \\
\text { individuals, } \\
\text { organizations } \\
\text { and society. }\end{array}$ & \multicolumn{2}{|c|}{$\begin{array}{l}\text { Students analyze local and/or global } \\
\text { impacts of computing on individuals, } \\
\text { organizations and society. Student } \\
\text { analysis may be superficial. }\end{array}$} & \multicolumn{2}{|c|}{$\begin{array}{l}\text { Students analyze local and global } \\
\text { impacts of computing on individuals, } \\
\text { organizations and society. Students } \\
\text { begin to recognize the associated } \\
\text { complexities and interdependencies. }\end{array}$} & $\begin{array}{l}\text { Students judiciously analyze local and } \\
\text { global impacts of computing on indi- } \\
\text { viduals, organizations and society. } \\
\text { Students recognize the associated } \\
\text { complexities and interdependencies. }\end{array}$ \\
\hline
\end{tabular}


CPSA 6. Students will be able to recognize when they need to seek further information to extend their knowledge.

\begin{tabular}{|c|c|c|c|c|c|}
\hline 0 - Missing & 1 - Emerging & 2 -Developing & 3 - Practicing & 4 - Maturing & 5 - Mastering \\
\hline $\begin{array}{l}\text { Students do } \\
\text { not refer to or } \\
\text { evaluate in- } \\
\text { formation } \\
\text { presented. }\end{array}$ & \multicolumn{2}{|c|}{$\begin{array}{l}\text { Students refer to the sources of } \\
\text { information presented during the } \\
\text { discussion. }\end{array}$} & \multicolumn{2}{|c|}{$\begin{array}{l}\text { Students evaluate the sources of in- } \\
\text { formation presented during the dis- } \\
\text { cussion. }\end{array}$} & $\begin{array}{l}\text { Students critically evaluate infor- } \\
\text { mation presented in the scenario and } \\
\text { presented during the discussion. Ex- } \\
\text { amples include, but are not limited to: } \\
\text { discussing potential and probable } \\
\text { biases of the information sources, } \\
\text { distinguishing fact from opinion in } \\
\text { order to determine levels of infor- } \\
\text { mation validity, analyzing implied } \\
\text { information. }\end{array}$ \\
\hline $\begin{array}{l}\text { Students do } \\
\text { not differenti- } \\
\text { ate between } \\
\text { what they do } \\
\text { and do not } \\
\text { know. }\end{array}$ & \multicolumn{2}{|c|}{$\begin{array}{l}\text { Students begin to identify what they } \\
\text { do and do not know. }\end{array}$} & \multicolumn{2}{|c|}{$\begin{array}{l}\text { Students identify what they do and do } \\
\text { not know. }\end{array}$} & $\begin{array}{l}\text { Students accurately identify the specif- } \\
\text { ic limits of their knowledge and how } \\
\text { those limitations affect their analysis. }\end{array}$ \\
\hline $\begin{array}{l}\text { Students do } \\
\text { not demon- } \\
\text { strate an } \\
\text { awareness of } \\
\text { the need to } \\
\text { seek additional } \\
\text { information. }\end{array}$ & \multicolumn{2}{|c|}{$\begin{array}{l}\text { Students may acknowledge the need } \\
\text { to seek additional information. }\end{array}$} & \multicolumn{2}{|c|}{$\begin{array}{l}\text { Students provide additional sources to } \\
\text { support the discussion and extend } \\
\text { their knowledge. }\end{array}$} & $\begin{array}{l}\text { Students actively seek relevant addi- } \\
\text { tional information and bring forth a } \\
\text { variety of reliable sources to support } \\
\text { the discussion and extend their } \\
\text { knowledge. }\end{array}$ \\
\hline
\end{tabular}

\section{BIOGRAPHIES}

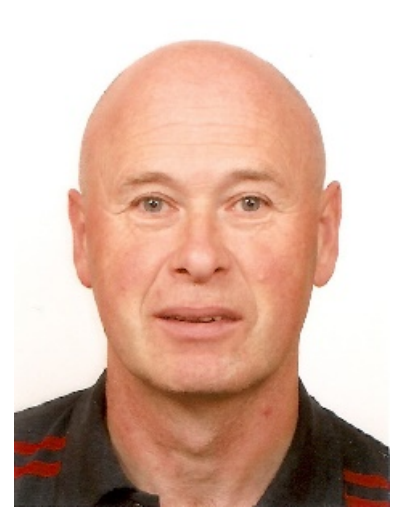

Dr Maurice Danaher is an Associate Professor in the College of Technological Innovation at Zayed University in the United Arab Emirates. He received his $\mathrm{PhD}$ in Information Systems in 2003 from Swinburne Institute of Technology, Melbourne, Australia. His research interests are in Information Technology and Quality Assurance in IT Education. He has published his work in these areas and has over 50 refereed publications. He has won a number of grants in the UAE totaling over US $\$ 250,000$ for research into quality assurance of IT education.

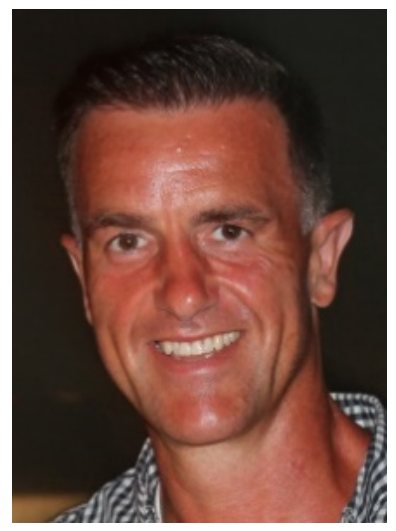

Dr Kevin Schoepp is currently working independently as a researcher. He has a M.A. in educational technology and an Ed.D. in higher education leadership from the University of Calgary, Canada. Until recently he held the position of Director of Academic Excellence at Jumeira University, Dubai, UAE. Prior to that he was the Director of Educational Effectiveness at Zayed University, UAE. He has published more than 33 articles and book chapters and delivered more than 40 conference presentations. His current research interests include assessment and learning outcomes in higher education. 


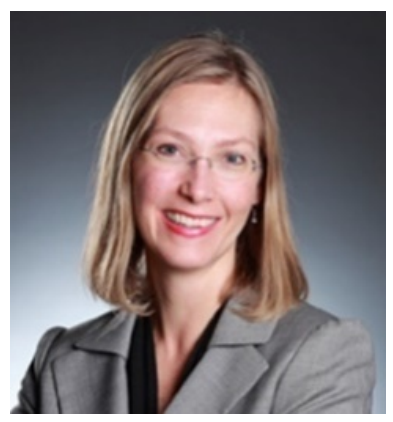

Dr Ashley Ater Kranov is an adjunct associate professor in School of Electrical Engineering and Computer Science at Washington State University. She received her $\mathrm{PhD}$ in adult and organizational learning from the University of Idaho, USA in 2006. From 2011 to 2013, Dr. Ater Kranov served as Managing Director of Professional Services at ABET. Her research areas of interest are direct methods to teach and measure professional skills necessary for 21 st century engineering and computing workplace success and how to increase gender equity in the technical fields. 